\title{
STUDY ON THE EFFECT OF PLANTING METHODS, PHOSPHORUS FERTILIZER AND SPRAYING WITH SOME NUTRIENTS UNDER NEWLY RECLAIMED SOILS ON YIELD AND QUALITY OF SUGAR BEET (BETA VULGARIS L.) Sahar F.Tawfic Sugar Crop Res. Inst , Agric. Res. Center, Giza, Egypt
}

\begin{abstract}
Two field studies were conducted in 2012/2013 and 2013/2014 growing seasons at Nubaria city Alexandria Governorate, Egypt during the two successive seasons, using sugar beet cultivar pleno to asses the effects of planting methods, phosphorus fertilizer management and spraying with some nutrients on sugar beet yield and quality. Split- split plot design was used with four replicates. The plot area was $27 \mathrm{~m}^{2}$. The main plots were assigned to two seedling methods

1- Manual planting, and 2- Mechanical planting.

The sub plots were assigned to two times for phosphorus fertilizer application:-

1-Application of the recommended phosphorus fertilizer as one dose before the planting 2- Application of the phosphorus as two equal doses, the first before the planting and the second one month after sowing.

The sub- sub plots were assigned to four nutrient spraying 1-Water as control, 2- Magnesium (400 mg L${ }^{-1}$ ) as $\mathrm{MgSO}_{4}$, 3- Boron, (150 $\left.\mathrm{mg} \mathrm{L}^{-1}\right)$ as boric acid and 4- Spraying with solution contain $150 \mathrm{mg} \mathrm{L}^{-1}$ boron $+400 \mathrm{mg} \mathrm{L}^{-1}$ magnesium. The obtained results can be summarized as follows:-

Mechanical planting method, application of phosphorus fertilizer at two equal doses and spraying with $\mathrm{B}+\mathrm{Mg}$ for sugar beet planting gave the highest values of root length, root fresh weight, root yield, sugar yield and sucrose $\%$ where as root diameter and top yield gave the highest values with manual planting and addition phosphorus fertilizer at one dose during land preparation, while addition some nutrients had no effected on top yields at two growing seasons. On the other hand migration coefficient not affected in both seasons by factors under study.

Impurities values were affected significantly by manual planting and addition phosphorus as one dose in both seasons while, some nutrients not affected on impurities values in both seasons and recorded the highest values.

Quality \% and extractable sugar (ton/fed.) recorded the highest values in both seasons when sugar beet plants were sowed mechanically and phosphorus was added at two equal doses where as, addition $\mathrm{B}+\mathrm{Mg}$ alone or mixture not affected on these traits in the first seasons only.
\end{abstract}

\section{INTRODUCTION}

Sugar beet is becoming an important crop as a source of sugar, because it grows well in the new reclaimed soils, mature in short period compared to sugar cane and contain high sugar content. Many environmental and agronomic factors influence sugar beet quantity and quality.

Shortage of farm labour and high costs has become a major constraint to economical agricultural production in Egypt. Over the past years much works and development has gone into producing implements and machines that will reduce the amount of labour required to grow the crop as 
well as the required seeds for planting. In comparative study between manual and mechanical planting of sugar beet Taieb (1990) reported that the density of plants in the mechanical planting treatment was about 12 plants per square meter, while the density of plants in the manual planting treatment was about 9 plants per square meter. He found that the yield of the harvested roots in the manual planting was 35.95 ton/fed., while the yield of the harvested roots in the mechanical planting was 42.34 ton/fed. Taieb (1997) stated that the mechanical planting of sugar beet saved $33 \%$ of seeds rate compared with the manual planting, decreased the costs of consumed energy (L.E/K.W.h) by to $58 \%$ and increased sugar beet yield form 29.22 to 34.38 ton/fed. per manual and mechanical planting, respectively.

Fertilization is the most important limiting factor to manipulate for sugar beet production under Egyptian soil environmental conditions (ElKammah, 1995). Adequate fertilization increased sugar beet root and white sugar yield (Sayed et al.,(1998), Abd El-Magid et al., (1999), Abu El-Fotoh et al., (2000) and Knany et al., 2005).

Phosphate supply could be a major limiting factor for increasing plant growth. The vital role of phosphorus in reactions involving energy transfer and more specifically ATP in nitrogen as activity. Most Egyptian soils are alkaline in reaction, the available $P$ level for plants is usually less since it rapidly converts to unavailable form and this becomes inaccessible by plants (Mahmoud and Abd El-Hafez, 1982). In such case the possible ways to increase plant available phosphorus are the use of phosphate solubilizing microorganisms (Hamissa et al., (2000) and Knany et al., 2004), by decreasing soil pH (Knany et al., (2000), Atia (2005) and El-Saady, 2004) or/and by splitting the phosphorus fertilizer (Verma et al., (1996); El-Far et al., (2001); Mahmoud, 2001, Knany et al., (2002) and Shafeek, (2003).

Many investigators studied response of sugar beet yield and its quality to spraying with some micronutrients. Voth (1978) found that boron fertilization significantly increased both sugar yield and quality. Boron fertilization significantly increased root yield, root/shoot ratio and migration coefficient with increments over the control by $4.53 \%, 11.42$ and 1.3 at $3 \mathrm{~kg}$ B /fed. However, shoots yield declined by $5.54 \%$ (El-Kammah, (1995). Ghaly et al. (1984) observed that sugar beet yield and sugar beet content of sugar were affected by boron application.

The objective of the present study is to investigate the effects of manual and mechanical seedlings, phosphorus fertilizer management and spraying with some nutrients on sugar beet yield and quality.

\section{MATERIALS AND METHODS}

Two field studies were conducted in 2012/2013 and 2013/2014 seasons at Nubaria city Alexandria Governorate growing seasons, Egypt during the two successive seasons, Egypt on sugar beet crop (Beta vulgares), variety pleno to assess planting methods, phosphorus fertilizer management and spraying with some nutrients on sugar beet yield and quality.

Split -split plot design was used with four replicates. The main plots 
were assigned by two planting methods, 1-Manual planting, and 2Mechanical planting. The sub-plots were assigned by two times of phosphorus fertilizer placement of 1 - Placement of the recommended

Phosphorus fertilizer at one dose before seedling and 2- Placement of the recommended phosphorus fertilizer at two equal doses, the first before seedling and the second after thinning (one month after seedling). The sub sub plots were randomly assigned by four nutrients spraying,

1- Spraying with water as check treatment, 2- Spraying with solution contain $400 \mathrm{mg} \mathrm{L}^{-1}$ Magnesium as $\mathrm{MgSO}_{4}$,

3- Spraying with solution contained $150 \mathrm{mg} \mathrm{L}^{-1}$ boron as boric acid and

4- Spraying with solution contain $150 \mathrm{mg} \mathrm{L}^{-1}$ boron $+400 \mathrm{mg} \mathrm{L}^{-1}$ magnesium.

The plot area was 27 square meter. The volume of spraying solution was two litters per plot.

Phosphorus fertilizer was added as calcium super phosphate $(15.5 \%$ $\mathrm{P}_{2} \mathrm{O}_{5}$ ). The recommended nitrogen and potassium fertilizers were added. Soil samples were taken before seedling for monitoring nutrients status and some chemical and physical properties according to Black et al. (1965). Root and top yields were noticed and migration coefficient was calculated as:-

Migration coefficient $=$ Root weight $\mathrm{kg} /$ Total plant weight $\mathrm{kg}$

Table(1): Physical and chemical properties of the experimental soils.

\begin{tabular}{|c|c|c|c|c|c|c|c|c|c|c|c|c|}
\hline \multirow[t]{2}{*}{ Seasons } & \multicolumn{3}{|c|}{ Partial size \% } & \multirow{2}{*}{\begin{tabular}{|c|} 
Soil \\
Textural \\
$\%$
\end{tabular}} & \multirow{2}{*}{$\begin{array}{c}\text { Soil pH } \\
1: 2.5\end{array}$} & \multirow{2}{*}{$\begin{array}{l}\text { E.C }{ }^{\star} \\
\text { ds } / \mathrm{m}\end{array}$} & \multirow{2}{*}{$\begin{array}{c}\text { CaCO3 } \\
\%\end{array}$} & \multirow{2}{*}{$\begin{array}{c}\text { Organic } \\
\text { matter } \\
\%\end{array}$} & \multicolumn{4}{|c|}{$\begin{array}{c}\text { Available contents } \\
\%\end{array}$} \\
\hline & Clay & \begin{tabular}{|l|} 
Silt \\
\end{tabular} & Sand & & & & & & $\mathbf{N}$ & $\mathbf{P}$ & & $\mathrm{K}$ \\
\hline & 3. & 3 & & Sandy & & 1.6 & $106 \%$ & 0.75 & 4.4 & 3.21 & & 132 \\
\hline & & 4 & & San & & & & & 6.5 & 3.01 & & 120 \\
\hline & & & & & & & & & & $\begin{array}{l}\text { able c } \\
\text { (ppm }\end{array}$ & $\cdots$ & \\
\hline & & & & $\mathrm{K}+$ & & $\mathrm{HCO}-$ & & SO4- & B & $\mathrm{Fe}$ & $\mathrm{Zn}$ & $\mathrm{Mn}$ \\
\hline & 2.00 & & 3. & 0.25 & 2.50 & & 3.02 & 2.17 & 0.31 & 4.2 & 2.6 & 3.8 \\
\hline 4 & 2 & 3.00 & 3.14 & 0.35 & 2.60 & 1.09 & 3.00 & 2.10 & 0.35 & 4.1 & 3.5 & 2.4 \\
\hline
\end{tabular}

*In the soil paste extract.

\section{Recorded data:}

At maturity (age of 210 days), the three middle rows of each plot were harvested to determine the following traits:

\section{Quality characteristics:-}

Samples of twenty roots were taken randomly, send to the laboratory, cleaned with running tap water, dried, each sample was grated separately with grater into cassettes and mixed thoroughly to determine the quality characteristics as described in Cooke and Scott (1993) .

1- Sucrose percentage was determined according to Le Docte (1927).

2- Purity percentage: It was estimated according to the following equation

Purity \%= 99.36 $-\{14.27(\mathrm{~V} 1+\mathrm{V} 2+\mathrm{V} 3 / \mathrm{V} 4)\}$

Where: $\mathrm{V} 1=\mathrm{Na}, \mathrm{V} 2=\mathrm{K}, \mathrm{V} 3=\alpha$-amino-N, $\mathrm{V} 4=$ sucrose $\%$.

3- $\alpha$ - amino nitrogen, sodium and potassium contents as milliequivalent per $100 \mathrm{~g}$ beet were estimated according to AOAC (2005) . 


\section{Productivity traits:-}

1. Root yield and top yield (ton/fed.): Plants of sugar beet from each plot were harvested topped to determine root yield and top yield as ton/fed. on fresh weight basis.

2. sugar yield (ton/fed.) was calculated using the following equation: sugar yield (ton/fed.) $=$ Root yield (ton/fed.) $x$ sucrose $\%$.

Data collected were subjected to the proper analysis of variance (ANOVA) to Gomez and Gomez (1984). Differences among treatments were evaluated by the least significant difference (LSD) at $5 \%$ level. Homogeneity of variance was examined before combined analysis. Some properties of the experimental soils (Table 1 ). sowing.

The spraying practice was repeated three times the first 45 days from

The second and the third sprays were one month between each other.

\section{RESULTS AND DISCUSSION}

\section{1-Root dimensions}

\section{1a- Root length and root diameter $(\mathrm{cm})$ :-}

Data tabulated in Table (2) show that significant differences were observed between mean values of it in both seasons resulted from planting methods. Mechanical planting for sugar beet seeds gave maximum values of root length compared to manual planting these superiority resulted from high density of mechanical planting which encourage roots to extended in the soil and gave longest root, while manual planting gave maximum values of root diameter. Application phosphorus fertilizer at two equal doses one during land preparation and after one month later gave the highest values of root dimensions more than addition all amount in one dose during land preparation before planting.

Table 2: Effect of planting methods, phosphorus management and spraying with some nutrients on sugar beet yield components.

\begin{tabular}{|c|c|c|c|c|c|c|c|c|}
\hline \multirow[t]{2}{*}{ Treatments } & \multicolumn{2}{|c|}{\begin{tabular}{|c|} 
Root length, \\
cm
\end{tabular}} & \multicolumn{2}{|c|}{$\begin{array}{c}\text { Root } \\
\text { diameter, } \mathbf{c m}\end{array}$} & \multicolumn{2}{|c|}{$\begin{array}{l}\text { Root fresh } \\
\text { weight, } \mathrm{g}\end{array}$} & \multicolumn{2}{|c|}{\begin{tabular}{|l|} 
Total Soluble \\
solids (TSS\%)
\end{tabular}} \\
\hline & $\begin{array}{l}\text { 1st } \\
1 \text { st }\end{array}$ & 2nd & 1st & 2nd & 1st & $\begin{array}{l}\text { 2nd } \\
\text { 1st }\end{array}$ & 1st & 2nd \\
\hline Mechanical planting (S1) & 29.25 & 30.35 & 10.45 & 10.68 & 981.67 & 1012.2 & 20.29 & 20.54 \\
\hline Manual plar & 26.32 & 27.40 & 11.35 & 11.65 & 1174.5 & 1212.3 & 18.30 & 18.95 \\
\hline F-test & $\ddot{\bullet}$ & $\ddot{*}$ & $\ddot{\bullet}$ & 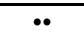 & $\ddot{\bullet}$ & $\ddot{\bullet}$ & $\ddot{\bullet}$ & $\ddot{\bullet}$ \\
\hline $\mathrm{P}$ as one dose & 25.85 & 26.34 & 10.56 & 10.78 & 975.32 & 1075.6 & 18.65 & 19.10 \\
\hline $\mathrm{P}$ as two doses & 27.93 & 28.46 & 11.02 & 11.32 & 1132.54 & 1189.5 & 20.15 & 20.98 \\
\hline F-test & $\ddot{\bullet}$ &  & 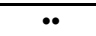 &  & $\ddot{\bullet}$ & $\ddot{*}$ & 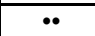 & $\ddot{\bullet}$ \\
\hline \multicolumn{9}{|l|}{ Foliar spraying treat. } \\
\hline Check & 28.35 & 29.15 & 11.37 & 11.54 & 1212.3 & 1254.6 & 20.25 & 20.68 \\
\hline $\mathrm{Mg}$ & 26.56 & 27.25 & 10.85 & 11.12 & 1145.3 & 1187.6 & 19.75 & 20.65 \\
\hline & 28.95 & 29.15 & 11.58 & 11.75 & 1265.3 & 1310.3 & 20.65 & 21.25 \\
\hline$M g+B$ & 28.80 & 29.00 & 11.75 & 12.00 & 1295.4 & 1365.8 & 21.75 & 22.15 \\
\hline F-test & $\bullet$ & $\ddot{\bullet \bullet}$ & $\ddot{\bullet}$ & 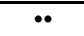 & $\ddot{\bullet \bullet}$ & 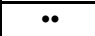 & $\ddot{\bullet \cdot}$ & $\ddot{\bullet \bullet}$ \\
\hline L.S.D. 0.05 & 1.41 & 1.21 & 0.45 & 0.32 & 22.98 & 25.15 & 0.25 & 0.35 \\
\hline
\end{tabular}


Regarding to foliar spraying with micronutrients, spraying $\mathrm{Mg}+\mathrm{B}$ gave the highest values of root dimensions compared to addition any one alone or control. Similar findings were found by El-Kammah (1995), Taieb (1997), Awad et al (2012), Awad et al (2013a and b) and Awad et al (2014).

Significant interaction effect was found between planting method $x$ spraying with some nutrients in both seasons. The highest root dimensions were observed resulted from mechanical planting and spraying mixture from $\mathrm{B}$ or $\mathrm{B}+\mathrm{Mg}$ this was true in both seasons.

2- Root fresh weight (g) and total soluble solids (Tss \%).

\section{a- Root fresh weight $(\mathbf{g})$ :-}

Results in Table (2) appeared a significant superiority in root fresh weight $(\mathrm{g})$ due to manual planting ( 1174.5 and $1212.3 \mathrm{~g})$ compared to mechanical planting (981.67 and $1012.2 \mathrm{~g}$ ) in both seasons respectively were found by El-Kammah (1995) and Taieb (1997).

Application phosphorus at equal doses the first before planting and the second after one month later gave the heavy root weights in both seasons compared with addition at one dose during land preparation.

Foliar spraying with mixture from $B+M g$ gave the highest root fresh weight/plant more than applied any one alone because two element gave plants two important elements at the same time.

b-Total soluble solids \%.:-

Concerning the effect of plant methods on total soluble solids in Table 3 cleared that mechanical planting exhibited significant differences among mean values of this trail in both seasons. Maximum values were recorded with mechanical planting because root size was small which increased total soluble solids compared to manual planting which gave big size and low (TSS \%).

Phosphorus fertilizer which added at two equal doses gave the highest soluble solids (20.15 and $20.98 \%)$ in both seasons. Significant differences were observed among (TSS \%) values related to applied foliar spraying the mixture from $\mathrm{B}+\mathrm{Mg}$ which progressive than applied any nutrient alone El-Kammah, (1995) and Taieb (1997). These results due to the important role of boron for sucrose transition in roots and role of magnesium as the central atom in chlorophyll it also plays on indispensable role in protein synthesis as abridging element for the aggregation of ribosome units and also, enzyme activation and energy transfer in plant for these advantages the applied of its together gave significant effect in increased (TSS \%).

The interaction effect between mechanical planting $x$ spraying some nutrients on root fresh weight and total soluble solids were significant in both seasons one presented in Table (3). Maximum root fresh weight was found with manual planting and fertilization with $\mathrm{B}+\mathrm{Mg}$ whereas, maximum values of (TSS \%) were obtained when sugar beet planted mechanical and fertilized as foliar application with boron only. 
Table 3: Effect of the interaction between planting methods and spraying with some nutrients on sugar beet yield components.

\begin{tabular}{|l|c|c|c|c|c|c|c|c|}
\hline \multirow{2}{*}{ Treatments } & \multicolumn{2}{|c|}{$\begin{array}{c}\text { Root length, } \\
\text { cm. }\end{array}$} & \multicolumn{2}{c|}{$\begin{array}{c}\text { Root } \\
\text { diameter, } \\
\text { cm. }\end{array}$} & \multicolumn{2}{c|}{$\begin{array}{c}\text { Root fresh } \\
\text { weight, g }\end{array}$} & \multicolumn{2}{c|}{$\begin{array}{c}\text { Total Soluble } \\
\text { solids } \\
\text { (TSS\%) }\end{array}$} \\
\cline { 2 - 9 } & 1st & 2nd & 1st & 2nd & 1st & 2nd & 1st & 2nd \\
\hline Mechanical planting & 28.15 & 28.45 & 9.85 & 10.10 & 1075.3 & 1098.7 & 20.65 & 20.85 \\
S1 & 26.65 & 27.15 & 10.02 & 10.20 & 1032.5 & 1065.3 & 20.42 & 20.65 \\
S1xMg & 28.95 & 29.32 & 10.12 & 10.32 & 1095.5 & 1108.4 & 20.84 & 20.95 \\
S1,xB & 28.85 & 29.45 & 10.32 & 10.45 & 1103.5 & 1174.6 & 20.74 & 20.85 \\
S1x Mg + B & 25.98 & 26.32 & 10.55 & 10.75 & 1115.3 & 1195.5 & 19.98 & 20.12 \\
\hline \$2 Manual planting & 25.75 & 26.40 & 10.32 & 10.45 & 1074.3 & 1122.5 & 20.10 & 20.32 \\
S2x Mg & 26.12 & 26.75 & 10.65 & 10.74 & 1095.4 & 1165.4 & 20.45 & 20.61 \\
S2,xB & 26.54 & 27.01 & 10.55 & 10.65 & 1100.5 & 1123.8 & 20.55 & 20.64 \\
S2 x Mg + B & $* *$ & $* *$ & $* *$ & $* *$ & $\star *$ & $* *$ & $* *$ & $*$ \\
\hline F-test & 0.74 & 0.65 & 0.25 & 0.32 & 4.12 & 3.21 & 0.45 & 0.36 \\
\hline L.S.D. 0.05 & & & & & & & & \\
\hline
\end{tabular}

Root and top yields (ton/fed.)

a-Root yield (ton/fed.):-

The obtained data in Table (4) reveal that the mechanical method for sugar beet planting gave the highest yields in both seasons compared to other method which gave the lowest one. These results due to high density which resulted from mechanical more than manual method which gave lowest root yield.

Table 4: Effect of planting methods, phosphorus management and spraying with some nutrients on sugar beet yield and quality.

\begin{tabular}{|c|c|c|c|c|c|c|c|c|c|c|}
\hline \multirow[t]{2}{*}{ Treatments } & \multicolumn{2}{|c|}{$\begin{array}{c}\text { Root yield } \\
\text { ton/fed. }\end{array}$} & \multicolumn{2}{|c|}{$\begin{array}{l}\text { Top yield } \\
\text { ton/fed. }\end{array}$} & \multicolumn{2}{|c|}{$\begin{array}{c}\text { Sucrose } \\
\%\end{array}$} & \multicolumn{2}{|c|}{$\begin{array}{c}\text { Sugar } \\
\text { yield } \\
\text { ton/fed. }\end{array}$} & \multicolumn{2}{|c|}{$\begin{array}{l}\text { Migration } \\
\text { coefficient }\end{array}$} \\
\hline & 1st & 2nd & 1st & 2nd & 1st & 2nd & 1st & 2nd & 1st & 2nd \\
\hline $\begin{array}{l}\text { Mechanical planting (S1) } \\
\text { Manual planting (S2) }\end{array}$ & $\begin{array}{l}26.47 \\
22.82 \\
\end{array}$ & \begin{tabular}{|l|}
27.68 \\
24.01 \\
\end{tabular} & \begin{tabular}{|l|}
11.15 \\
12.98 \\
\end{tabular} & $\begin{array}{l}13.38 \\
13.68 \\
\end{array}$ & \begin{tabular}{|l|}
17.35 \\
16.09 \\
\end{tabular} & $\begin{aligned} 18.00 \\
16.100 \\
\end{aligned}$ & $\begin{array}{l}4.59 \\
3.67 \\
\end{array}$ & $\begin{array}{l}4.98 \\
3.86 \\
\end{array}$ & $\begin{array}{l}0.72 \\
0.66 \\
\end{array}$ & $\begin{array}{l}0.71 \\
0.66 \\
\end{array}$ \\
\hline F-test &  & 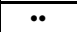 & 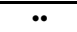 & 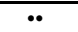 & 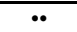 & 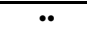 & 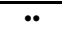 & 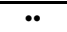 & & \\
\hline $\begin{array}{l}\mathrm{P} \text { as one dose } \\
\mathrm{P} \text { as two doses }\end{array}$ & $\begin{array}{l}23.95 \\
24.26 \\
\end{array}$ & $\begin{array}{l}25.07 \\
25.63 \\
\end{array}$ & \begin{tabular}{|l|}
12.08 \\
11.05 \\
\end{tabular} & $\begin{array}{l}12.17 \\
11.18 \\
\end{array}$ & \begin{tabular}{|l|}
16.15 \\
17.74 \\
\end{tabular} & $\begin{array}{l}16.39 \\
17.69 \\
\end{array}$ & $\begin{array}{l}3.92 \\
4.25 \\
\end{array}$ & $\begin{array}{l}4.20 \\
4.43 \\
\end{array}$ & $\begin{array}{l}0.67 \\
0.70\end{array}$ & $\begin{array}{l}0.67 \\
0.70 \\
\end{array}$ \\
\hline F-test & $\ddot{*}$ & $\ddot{*}$ & $\ddot{*}$ & $\ddot{*}$ & 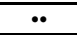 & $\ddot{*}$ & $\ddot{*}$ & & $\cdot$ & \\
\hline \multicolumn{11}{|l|}{ Foliar spraying treat. } \\
\hline $\begin{array}{l}\text { Check } \\
\mathrm{Mg} \\
\mathrm{B} \\
\mathrm{Mg}+\mathrm{B} \\
\end{array}$ & $\begin{array}{l}25.50 \\
23.73 \\
25.64 \\
25.60 \\
\end{array}$ & \begin{tabular}{|l|}
25.61 \\
23.99 \\
25.81 \\
25.98 \\
\end{tabular} & \begin{tabular}{|l|}
11.26 \\
12.38 \\
11.65 \\
10.95 \\
\end{tabular} & $\begin{array}{l}11.48 \\
12.35 \\
11.84 \\
11.03 \\
\end{array}$ & \begin{tabular}{|l|}
17.54 \\
17.49 \\
17.67 \\
17.69 \\
\end{tabular} & $\begin{array}{l}17.50 \\
17.44 \\
17.56 \\
17.61 \\
\end{array}$ & $\begin{array}{l}4.47 \\
4.15 \\
4.53 \\
4.53 \\
\end{array}$ & $\begin{array}{l}4.48 \\
4.18 \\
4.53 \\
4.58 \\
\end{array}$ & $\begin{array}{l}0.69 \\
0.66 \\
0.69 \\
0.70 \\
\end{array}$ & \begin{tabular}{|l}
0.69 \\
0.66 \\
0.68 \\
0.70 \\
\end{tabular} \\
\hline F-test & $\bullet$ & 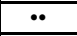 & N.S & N.S & N.S & N.S & $\cdot$ & $\cdot$ & & \\
\hline L.S.D. 0.05 & 1.83 & 1.61 & - & - & - & - & 0.33 & 0.56 & & \\
\hline
\end{tabular}

Addition phosphorus fertilizer at two different times (during land preparation and after month later) gave the highest root yield whereas, addition all dose before planting gave the lowest yields in both seasons.

Fertilization with mixture from $\mathrm{B}+\mathrm{Mg}$ as foliar spraying for sugar beet gave the highest root yield compared with addition any one alone. These advantage due to the important role for every and collection between then in one plant. Similar findings were found by El-Kammah (1995), Taieb (1997), Awad et al (2012), Awad et al (2013 a and b) and Awad et al (2014). 


\section{b. Top yield (ton/fed.):-}

Data presented in Table (4) pointed out that significant differences were found between values of top yield in both seasons due to planting methods. In the first season manual planting gave the highest top yield whereas, in the second season, planting sugar beet seeds mechanically gave the highest yield. Phosphorus fertilizer which added as one dose before planting gave the highest top yield than which spilling before planting and the other half after one month later.

This progressive due to addition phosphorus before planting and during land preparation gave a good chance to become available to plant during growing season than late addition which caused to reduced the availability of element to plant El-Kammah (1995), Taieb (1997), Awad et al (2012) and Awad et al (2013 a and b) found the same trend.

No significant differences were obtained due to addition of some nutrients ( $\mathrm{B}$ or $\mathrm{Mg}$ ) on top yield during both seasons. Significant interaction effects were found between planting methods $x$ some nutrients on top yield in both seasons in Table (5). Manual planting and spraying with Mg only gave the highest top yield because manual planting have low density which gave a good chance to gave maximum leaf area and gave the highest top yield than other plant method and other addition of some nutrients.

The other significant interaction effect were found in both seasons between planting method $x$ time of phosphorus addition $x$ spraying some nutrients on top yield in Table (6). Manual planting and fertilized by phosphorus as one dose before planting and spraying with $\mathrm{Mg}$ gave maximum top yield compare with other treatments under study.

\section{Sucrose \% and sugar yield (ton/fed.):-}

A speculative to the obtained results in Table (4) it could be remarked that the highest sucrose \% were found in both seasons resulted from mechanical planting than manual this result due to small size of root resulted from high density of mechanical method witch gave maximum sucrose percentage than manual. This was true in both seasons. El-Kammah (1995), Taieb (1997), Awad (2000), Knany et al (2005 a and b), Awad et al (2012) and Awad et al (2013 a and b) found the same trend.

Splitting Phosphorus fertilizer to two equal doses gave the highest sucrose concentration in roots than addition the same dose at on time before planting. No significant effect were found in both seasons caused by foliar spraying with some nutrients. As to, the influence of the interaction between the two studied factors planting method $x$ some nutrients, the collected data in Table ( 5 and 6 ) pointed out that, maximum sucrose \% were obtained (18.0 and $18.05 \%$ ) resulted from planting sugar beet mechanically and addition of phosphorus at two equal doses and foliar with mixture from $(B+M g)$ these was true in both seasons. 
Table 5: Effect of the interaction between planting methods and spraying with some nutrients on sugar beet yield and quality.



Table 6: Effect of the interaction between planting methods, phosphorus fertilizer management and spraying with some nutrients on sugar beet yield and quality.

\begin{tabular}{|c|c|c|c|c|c|c|c|c|c|c|c|c|}
\hline \multirow{2}{*}{\multicolumn{2}{|c|}{ Treatments }} & \multirow[t]{2}{*}{$\begin{array}{c}\text { Foliar } \\
\text { spraying } \\
\text { treat. }\end{array}$} & \multicolumn{2}{|c|}{$\begin{array}{l}\text { Root yield } \\
\text { ton/fed. }\end{array}$} & \multicolumn{2}{|c|}{$\begin{array}{c}\text { Top yield } \\
\text { ton/fed. }\end{array}$} & \multicolumn{2}{|c|}{$\begin{array}{c}\text { sucrose } \\
\%\end{array}$} & \multicolumn{2}{|c|}{$\begin{array}{c}\text { Sugar } \\
\text { yield } \\
\text { ton/fed. }\end{array}$} & \multicolumn{2}{|c|}{$\begin{array}{l}\text { Migration } \\
\text { coefficient }\end{array}$} \\
\hline & & & $\begin{array}{l}1^{\text {st }} \\
1^{\text {st }}\end{array}$ & $2^{\text {nd }}$ & $1^{\text {st }}$ & $2^{\text {nd }}$ & $1^{\text {st }}$ & $\begin{array}{l}2^{\text {nd }} \\
1^{\text {st }}\end{array}$ & $1^{\text {st }}$ & $2^{\text {nd }}$ & $1^{\text {st }}$ & $2^{\text {nd }}$ \\
\hline $\begin{array}{l}\text { Mechanical } \\
\text { planting }\end{array}$ & $\begin{array}{l}\text { P-one } \\
\text { dose }\end{array}$ & $\begin{array}{c}\text { Check } \\
M g \\
B \\
M g+B\end{array}$ & $\begin{array}{l}26.97 \\
24.12 \\
25.87 \\
26.34 \\
25.53\end{array}$ & $\begin{array}{l}24.77 \\
26.60 \\
27.16\end{array}$ & $\begin{array}{c}11.97 \\
9.44 \\
12.35 \\
9.40\end{array}$ & \begin{tabular}{|c|}
12.10 \\
9.59 \\
12.63 \\
9.57
\end{tabular} & $\begin{array}{l}17.56 \\
17.11 \\
17.09 \\
17.83\end{array}$ & $\begin{array}{l}17.81 \\
17.19 \\
17.12 \\
17.89\end{array}$ & \begin{tabular}{|l|}
4.75 \\
4.13 \\
4.42 \\
4.70
\end{tabular} & $\begin{array}{l}4.83 \\
4.26 \\
4.55 \\
4.86\end{array}$ & $\begin{array}{l}0.69 \\
0.73 \\
0.68 \\
0.73\end{array}$ & $\begin{array}{l}0.69 \\
0.71 \\
0.68 \\
0.73\end{array}$ \\
\hline$(\mathrm{S} 1)$ & $\begin{array}{l}P \text {-two } \\
\text { doses }\end{array}$ & $\begin{array}{c}\text { Check } \\
M g \\
B \\
M g+B\end{array}$ & $\begin{array}{c}27.7 \\
24.4 \\
26.9 \\
26.6 \\
25.08\end{array}$ & $\begin{array}{c}27.88 \\
24.9 \\
27.1 \\
26.98\end{array}$ & $\begin{array}{c}9.84 \\
10.75 \\
10.19 \\
9.27\end{array}$ & \begin{tabular}{|c|}
10.13 \\
11.00 \\
10.25 \\
9.52
\end{tabular} & $\begin{array}{l}17.84 \\
17.32 \\
17.20 \\
18.00\end{array}$ & \begin{tabular}{l|}
17.94 \\
17.40 \\
17.35 \\
18.05
\end{tabular} & \begin{tabular}{|l|}
4.94 \\
4.23 \\
4.63 \\
4.79
\end{tabular} & $\begin{array}{l}5.00 \\
4.33 \\
4.70 \\
4.87\end{array}$ & $\begin{array}{l}0.69 \\
0.73 \\
0.72\end{array}$ & $\begin{array}{l}0.73 \\
0.69 \\
0.72 \\
0.73\end{array}$ \\
\hline \begin{tabular}{|l|} 
Manual \\
planting
\end{tabular} & $\begin{array}{l}\text { P-one } \\
\text { dose }\end{array}$ & $\begin{array}{c}\text { Check } \\
\mathrm{Mg} \\
\mathrm{B} \\
\mathrm{Mg}+\mathrm{B}\end{array}$ & $\begin{array}{c}24.6 \\
23.11 \\
24.50 \\
25.49 \\
\end{array}$ & $\begin{array}{c}25.3 \\
23.67 \\
24.79 \\
25.73 \\
\end{array}$ & $\begin{array}{l}12.25 \\
17.59 \\
12.74 \\
12.87 \\
\end{array}$ & \begin{tabular}{|l|}
12.52 \\
17.39 \\
12.98 \\
12.72 \\
\end{tabular} & $\begin{array}{l}16.35 \\
16.20 \\
16.25 \\
16.70 \\
\end{array}$ & $\begin{array}{l}16.43 \\
16.55 \\
16.63 \\
16.95 \\
\end{array}$ & \begin{tabular}{|l|}
4.02 \\
3.74 \\
3.98 \\
4.24 \\
\end{tabular} & $\begin{array}{l}4.16 \\
3.92 \\
4.12 \\
4.30 \\
\end{array}$ & $\begin{array}{l}0.67 \\
0.59 \\
0.65 \\
0.66 \\
\end{array}$ & $\begin{array}{l}0.66 \\
0.59 \\
0.65 \\
\text { p.67 }\end{array}$ \\
\hline (S2) & $\begin{array}{l}P \text {-two } \\
\text { doses }\end{array}$ & $\begin{array}{c}\text { Check } \\
\mathrm{Mg} \\
\mathrm{B} \\
\mathrm{Mg}+\mathrm{B}\end{array}$ & $\begin{array}{l}24.9 \\
23.8 \\
24.9 \\
26.0 \\
\end{array}$ & $\begin{array}{l}25.2 \\
24.3 \\
25.3 \\
26.2 \\
\end{array}$ & $\begin{array}{l}11.98 \\
12.76 \\
11.32 \\
12.31 \\
\end{array}$ & \begin{tabular}{|l|}
12.28 \\
12.52 \\
11.50 \\
12.23 \\
\end{tabular} & $\begin{array}{l}16.54 \\
16.44 \\
16.54 \\
17.01 \\
\end{array}$ & \begin{tabular}{l|}
16.70 \\
16.77 \\
16.84 \\
17.20 \\
\end{tabular} & \begin{tabular}{|l|}
4.12 \\
3.91 \\
4.12 \\
4.42 \\
\end{tabular} & $\begin{array}{l}4.21 \\
4.10 \\
4.26 \\
4.51 \\
\end{array}$ & $\begin{array}{l}0.67 \\
0.64 \\
0.69 \\
0.68 \\
\end{array}$ & $\begin{array}{l}0.67 \\
0.65 \\
0.69 \\
0.70\end{array}$ \\
\hline \multicolumn{3}{|l|}{ F-test } & ** & $\star *$ & ** & ** & * & * & * & * & & \\
\hline \multicolumn{3}{|l|}{ L.S.D. 0.05} & 3.32 & 2.89 & 4.38 & 3.82 & 0.79 & 0.45 & 0.98 & 0.76 & & \\
\hline
\end{tabular}

\section{Sugar yield (ton/fed.):-}

Sugar yield is the final goal for every study, the obtained data in Table (4) declared that planting sugar beet with machine progressive than manual planting and gave the highest sugar yield (4.59 and 4.98 ton/fed.). These advantage resulted from maximum root yield and sucrose $\%$ for mechanical planting. Also, application of phosphorus at two equal dose significantly increased sugar yield than other time of application. Foliar spraying for some nutrients induced significant effect on sugar yield in both seasons El-Kammah (1995), Taieb (1997), Knany et al (2005 a and b) and Awad et al. (2013 a,b and c). 
Addition a mixture from $\mathrm{B}+\mathrm{Mg}$ had significant effect on sugar yield in both seasons than other additions. Regarding the interaction between the three studied factors, the data obtained in Table (5 and 6 ) revaled that a good treatment gave significant effect on sugar yield were mechanical planting $\mathrm{x}$ addition phosphorus at two equal doses $\mathrm{x}$ foliar spraying with some nutrients $(B+M g)$ then other factors under study.

Migration coefficient:-

Data presented in Table (4) cleared that all factors under study had different effects on migration coefficient in both seasons.

Impurities ( $\mathrm{Na}, \mathrm{K}$ and $\alpha$-amino-N):-

The obtained data in Table (7) revealed the influence of planting method, time of phosphorus application and foliar spraying of some nutrients on impurity values of ( $\mathrm{Na}, \mathrm{K}$ and $\alpha$-amino- $\mathrm{N}$ ).

Planting methods that significant effect on all impurities values on both seasons, manual method recorded the highest values, these increase in values due the increase in growth rate which related to large space between plants and increase in available nutrients than high density in other planting method were found by El-Kammah (1995), Taieb (1997), Awad(2000), Knany et al (2005 a and b) and Awad et al (2013 a,b and c).

Table 7: Effect of planting methods, phosphorus fertilizer management and spraying with some nutrients on sugar beet $\mathrm{K}, \mathrm{Na}, \alpha$-amino nitrogen, quality \% and extractable sugar ton/fed.

\begin{tabular}{|c|c|c|c|c|c|c|c|c|c|c|}
\hline \multirow[t]{2}{*}{ Treatments } & \multicolumn{2}{|c|}{$\mathrm{K}^{*}$} & \multicolumn{2}{|c|}{$\mathrm{Na}^{*}$} & \multicolumn{2}{|c|}{$\alpha$-amino $N^{\star}$} & \multicolumn{2}{|c|}{ Purity \% } & \multicolumn{2}{|c|}{$\begin{array}{c}\text { Extractable } \\
\text { Sugar } \\
\text { ton/fed. }\end{array}$} \\
\hline & 1st & 2nd & 1st & 2nd & 1st & 2nd & 1st & 2nd & 1st & 2nd \\
\hline Mechanical planting & 4.03 & 3.99 & 1.65 & 1.60 & 1.13 & 1.08 & 86.5 & 86.3 & 4.36 & 4.42 \\
\hline Manual planting & 4.35 & 4.33 & 1.97 & 1.89 & 1.40 & 1.56 & 84.7 & 84.9 & 4.07 & 4.05 \\
\hline F-test & *夫 & ** & 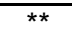 & ** & ** & *夫 & ** & *夫 & ** & N.S \\
\hline $\mathrm{P}$ in one dose & 5.25 & 5.17 & 1.93 & 1.99 & 1.32 & 1.47 & 85.2 & 85.3 & 4.22 & 4.19 \\
\hline$P$ in two doses & 5.16 & 5.15 & 1.69 & 1.77 & 1.01 & 1.00 & 86.2 & 85.9 & 4.20 & 4.27 \\
\hline F-test & N.S & N.S & * & * & * & * & N.S & * & N.S & N.S \\
\hline \multicolumn{11}{|l|}{ Foliar spraying treat. } \\
\hline Check & 5.33 & 5.27 & 1.97 & 2.04 & 1.35 & 1.50 & 84.7 & 85.2 & 4.18 & 4.28 \\
\hline $\mathrm{Mg}$ & 5.28 & 5.31 & 1.83 & 1.91 & 1.38 & 1.51 & 85.9 & 85.5 & 3.97 & 3.94 \\
\hline$B$ & 5.09 & 5.00 & 1.75 & 1.80 & 1.17 & 1.35 & 85.8 & 85.6 & 4.34 & 4.31 \\
\hline$M g+B$ & 5.13 & 5.06 & 1.69 & 1.78 & 1.15 & 1.32 & 86.3 & 86.1 & 4.35 & 4.38 \\
\hline F-test & N.S & N.S & N.S & N.S & N.S & N.S & * & * & * & • \\
\hline L.S.D. 0.05 & - & - & - & - & - & - & 0.73 & 0.76 & 0.41 & 0.29 \\
\hline
\end{tabular}

${ }^{*}=$ Potassium, Sodium and $\alpha$ - amino nitrogen content as milliequavalents $/ 100 \mathrm{gm}$ beet.

Time of phosphorus application significantly affected on $\mathrm{Na}$ and $\alpha$ amino- $N$ which increased with addition phosphorus at one dose before planting. On the other side time of application had no effect on concentration of potassium in roots in both seasons. Regarding the effect of foliar application of some nutrients on sugar beet its clear that, no significant effect on all impurities content due to addition these element either along or together in both seasons. 
Concerning the interaction effect between the three factors under study on impurities values, data in Table (8) show that no significant effect were found in both seasons on ( $\mathrm{K}$ and $\mathrm{Na}$ ) while, there was significant effect on $\alpha$-amino- $N$ in both seasons due to manual planting which gave the highest values for $\alpha$-amino- $\mathrm{N}$ with control treatment compared to other treatments were found by El-Kammah (1995), Taieb (1997), Knany et al (2005 a and b) and Awad et al (2013 a,b and c).

Purity \%:-

The available data in Table (7) cleared that mechanical planting for sugar beet gave a high purity values and there were significant differences in values than manual planting which gave the lowest values of purity in both seasons these increase in purity due to high values of sucrose \% and low impurities values, were found by El-Kammah (1995), Taieb (1997), Knany et al (2005 a and b), Awad et al (2012), Awad et al (2013 a and b) and Awad et al (2014).

Table 8: Effect of the interaction between planting methods, phosphorus fertilizer management and spraying with some nutrients on sugar beet $\mathrm{K}, \mathrm{Na}, \alpha$-amino- $\mathrm{N}$, purity $\%$ and extractable sugar ton/ fed.

\begin{tabular}{|c|c|c|c|c|c|c|c|c|c|c|c|c|}
\hline \multirow{2}{*}{\multicolumn{2}{|c|}{ Treatments }} & \multirow{2}{*}{$\begin{array}{c}\text { Foliar } \\
\text { spraying } \\
\text { treat. }\end{array}$} & \multicolumn{2}{|c|}{$\mathbf{K}^{*}$} & \multicolumn{2}{|c|}{$\mathrm{Na}^{*}$} & \multicolumn{2}{|c|}{$\alpha$-amino $\mathbf{N}^{\star}$} & \multicolumn{2}{|c|}{ Purity\% } & \multicolumn{2}{|c|}{$\begin{array}{c}\text { Extractable } \\
\text { sugar } \\
\text { ton/fed. }\end{array}$} \\
\hline & & & 1st & 2nd & 1st & 2nd & 1st & 2nd & 1st & 2nd & 1st & 2nd \\
\hline $\begin{array}{l}\text { Mechanical } \\
\text { planting }\end{array}$ & $\begin{array}{l}\text { P-one } \\
\text { dose }\end{array}$ & $\begin{array}{c}\text { Check } \\
\mathrm{Mg} \\
\mathrm{B} \\
\mathrm{Mg}+\mathrm{B}\end{array}$ & $\begin{array}{l}5.12 \\
4.94 \\
5.02 \\
5.07\end{array}$ & $\begin{array}{l}5.03 \\
4.90 \\
4.85 \\
4.99\end{array}$ & $\begin{array}{l}1.76 \\
1.59 \\
1.92 \\
1.65\end{array}$ & $\begin{array}{l}1.79 \\
1.64 \\
1.93 \\
1.68\end{array}$ & $\begin{array}{l}1.34 \\
1.04 \\
1.21 \\
1.14\end{array}$ & $\begin{array}{l}1.47 \\
1.13 \\
1.42 \\
1.27\end{array}$ & $\begin{array}{l}80.2 \\
85.5 \\
84.0 \\
83.3\end{array}$ & \begin{tabular}{|l|}
83.2 \\
84.8 \\
83.8 \\
85.1 \\
\end{tabular} & $\begin{array}{l}3.90 \\
4.18 \\
4.03 \\
4.12 \\
\end{array}$ & \begin{tabular}{|l|}
3.95 \\
3.83 \\
3.90 \\
4.14 \\
\end{tabular} \\
\hline (S1) & $\begin{array}{l}\text { P-two } \\
\text { doses }\end{array}$ & $\begin{array}{c}\text { Check } \\
\mathrm{Mg} \\
\mathrm{B} \\
\mathrm{Mg}+\mathrm{B}\end{array}$ & $\begin{array}{l}4.91 \\
5.44 \\
5.09 \\
4.95\end{array}$ & $\begin{array}{l}4.87 \\
5.36 \\
5.04 \\
4.90\end{array}$ & $\begin{array}{l}1.46 \\
1.81 \\
1.54 \\
1.45\end{array}$ & $\begin{array}{l}1.50 \\
1.85 \\
1.59 \\
1.49\end{array}$ & $\begin{array}{l}0.99 \\
1.36 \\
1.02 \\
0.91\end{array}$ & $\begin{array}{l}1.13 \\
1.47 \\
1.23 \\
1.11\end{array}$ & $\begin{array}{l}85.0 \\
86.3 \\
86.6 \\
86.0\end{array}$ & \begin{tabular}{|l|}
84.6 \\
85.6 \\
86.3 \\
85.7
\end{tabular} & $\begin{array}{l}3.97 \\
3.79 \\
4.18 \\
4.38\end{array}$ & \begin{tabular}{|l|}
4.04 \\
3.86 \\
4.24 \\
4.41 \\
\end{tabular} \\
\hline $\begin{array}{l}\text { Manual } \\
\text { planting }\end{array}$ & $\begin{array}{l}\text { P-one } \\
\text { dose }\end{array}$ & $\begin{array}{c}\text { Check } \\
\mathrm{Mg} \\
\mathrm{B} \\
\mathrm{Mg}+\mathrm{B}\end{array}$ & $\begin{array}{l}5.40 \\
5.61 \\
5.34 \\
5.48\end{array}$ & $\begin{array}{l}5.35 \\
5.56 \\
5.29 \\
5.40\end{array}$ & $\begin{array}{l}2.50 \\
2.06 \\
1.98 \\
1.95\end{array}$ & $\begin{array}{l}2.58 \\
2.17 \\
2.04 \\
2.11\end{array}$ & $\begin{array}{l}1.27 \\
1.80 \\
1.33 \\
1.45\end{array}$ & $\begin{array}{l}1.42 \\
1.95 \\
1.48 \\
1.60\end{array}$ & $\begin{array}{l}86.4 \\
87.0 \\
86.1 \\
86.8\end{array}$ & \begin{tabular}{|l|}
86.2 \\
86.9 \\
85.9 \\
86.6
\end{tabular} & $\begin{array}{l}4.37 \\
4.10 \\
4.54 \\
4.55\end{array}$ & \begin{tabular}{|l|}
4.38 \\
4.18 \\
4.56 \\
4.63 \\
\end{tabular} \\
\hline$(\mathrm{S} 2)$ & $\begin{array}{l}\text { P-two } \\
\text { doses }\end{array}$ & $\begin{array}{c}\text { Check } \\
\mathrm{Mg} \\
\mathrm{B} \\
\mathrm{Mg}+\mathrm{B}\end{array}$ & $\begin{array}{l}5.89 \\
5.12 \\
4.91 \\
5.01\end{array}$ & $\begin{array}{l}5.84 \\
5.40 \\
4.81 \\
4.96\end{array}$ & $\begin{array}{l}2.17 \\
1.84 \\
1.59 \\
1.70\end{array}$ & $\begin{array}{l}2.28 \\
1.97 \\
1.66 \\
1.82\end{array}$ & $\begin{array}{l}1.82 \\
1.33 \\
1.11 \\
1.10\end{array}$ & $\begin{array}{l}1.97 \\
1.48 \\
1.28 \\
1.27\end{array}$ & $\begin{array}{l}87.2 \\
84.9 \\
86.6 \\
86.1\end{array}$ & \begin{tabular}{|l|}
86.9 \\
84.7 \\
86.3 \\
86.9
\end{tabular} & $\begin{array}{l}4.47 \\
3.83 \\
4.63 \\
4.36\end{array}$ & $\begin{array}{l}4.80 \\
3.88 \\
4.56 \\
4.35 \\
\end{array}$ \\
\hline $\mid 1-t e s t$ & & & N.S & N.S & N.S & N.S & * & $\bullet$ & N.S & N.S & N.S & N.S \\
\hline L.S.D. 0.05 & & & - & - & - & - & 0.87 & 0.92 & - & - & - & - \\
\hline
\end{tabular}

${ }^{*}=$ Potassium, Sodium and $\alpha$ - amino nitrogen content as milliequavalents $/ 100 \mathrm{gm}$ beet.

Phosphorus fertilizer which splitting to two equal doses gave the highest purity value in the $2^{\text {nd }}$ season only while in the first season there was no significant differences. Either application boron or magnesium had any effect on sugar beet quality in both seasons.

Concerning the interaction effect between the three factors under study on quality data in Table (8) show that no significant interaction effect were found in both seasons. 


\section{Extractable sugar (ton/fed.):-}

Extractable sugar (ton/fed.) is the important character for sugar beet. Data in Table (7) revealed the effect of planting method, time of phosphorus application and foliar spraying with some nutrients on extractable sugar (ton/fed.) in both seasons.

Planting method had significant effect on extractable sugar (ton/fed.) in the first season only. Mechanical planting gave the highest value (4.36 ton/fed.) compared with (4.07 ton/fed.) with manual planting were found by El-Kammah (1995), Taieb (1997), Knany et al (2005 a and b) and Awad et al (2013 a,b and c).

No significant differences were found in both season among values of extractable sugar resulted from time of phosphorus application. Addition some nutrients together $(B+M g)$ significantly affected on extractable sugar than addition any one alone these true in both seasons.Regarding the interaction effect between three factors under study in Table (8). There were no significant effect were found on extractable sugar in both seasons.

\section{CONCLUSION}

Quality \% and extractable sugar (ton/fed.) recorded the highest values in both seasons when sugar beet plants were sowed mechanically and phosphorus was added at two equal doses where as, addition $\mathrm{B}+\mathrm{Mg}$ alone.

\section{REFERENCES}

Abd El-Magid, A.A.; R.E. Knany and H.G. Abu El-Fotoh (1999). Using a natural hydrophilic polymer for improving sugar beet productivity. Recent Technologies in Agric. Proceedings of the 1st Congress. Cairo Univ. Fac. of Agric. 27-29 November pp. 861-868.

Abu El-Fotoh, H.G.; A.A. Abd El-Magid and R.E. Knany (2000). Effect of biofertilization on sugar beet yield, quality and optimization of the chemical fertilizers. Proc. 9th Conf. Agron., Minufiya Univ., 1-3 Sept.pp. 561-567.

Atia, R.H. (2005). Effect of sulphur, phosphorus and nitrogen addition on soybean productivity and quality. J. Agric. Sci. Mansoura Univ. 30(1):711-722.

A.O.A.C.(2005). Association of Official Analytical Chemists. Official methods of analysis, 26th Ed.

Awad, N.M. (2000). A study on the performance of two sugar beet planters one of them manufactured and developed to suit small holdings. Ph.D. Thesis, Ag. Mech. Dept., Fac. of Agric., Eng. Kafr El-Sheikh, Tanta Univ.

Awad, N. M.M.; Sahar,F.Tawfik and Sahr,M.I.Moustafa (2012). Effect of plowing depth, sowing method and nitrogen fertilization on yield and quality of sugar beet .J. Agric. Res. Kafr El-Sheikh Univ.38(4):458-470. 
Awad, N. M.M.; Sahar,F.Tawfik and Sahr,M.I.Moustafa (2013 a).Influence of foliar spray of some micronutrients and nitrogen fertilizer on productivity of sugar beet under newly reclaimed soils. J. Agric. Res. Kafr El-Sheikh Univ.39(2):181-194.

Awad, N. M.M.; Sahar,F.Tawfik and Sahr,M.I.Moustafa (2013 b). Response of two sugar beet varieties to nitrogen and magnesium fertilization at nubaria aria. J. Agric. Res. Kafr El-Sheikh Univ.39(2):195-209.

Awad, N. M.M.; H.s.Gharib and Sahr,M.I.Moustafa (2013 c). Response of sugar beet (Beta vulgaris L.) to potassium and sulphur supply in clayed soil at north delta, Egypt. Egypt. Agron. Vol.35. No.1,pp.77-99.

Awad, N. M.M.;A.Abdeldaiem and Sahr,M.I.Moustafa (2014). Evaluation of six sugar beet varieties under three harvesting dates. Minufiya $\mathrm{J}$. Agric.res. 39. 1(1):121-130.

Black, A.; D.D. Evans; J.L White; LE. Ensuminger and F.F. Clark (1965). Methods of Soil Analysis. Am. Soc. Agron. Inc. Pub. Madison, Wisconsin, U.S.A

Cooke, D.A. and R.K. Scott (1993). The Sugar Beet Crop. Science Practice published by Chapman \& Hall, London

El-Far, i.A.; A. Ghallab and G.R. El-Nagar (2001). Nutrients contents and yield of lupine as influenced by splitting $N, P, K$ fertilizers in a clay soil.Assiut. J. of Agric. Sci. 32(2): 1-22.

El-Kammah, M.A. (1995). Quantity and quality of sugar beet biomass as affected by interrelationships of water irrigation regimes and fertilization. J. Agric. Sci. Mansoura Univ., 20(12): 5250-5263.

El-Saady, A.S.M. (2004). Response of soybean to phosphogypsum and superphosphate application under the Egyptian soils conditions. J.Agric. Sci. Mansoura Univ., 29(7): 4337-4348.

Ghaiy, S.; I. Abdel Aziz and M. Moursy (1984). Response of sugar beet to K and B fertilization in Egyptian soi!. Agric. Res. Rev. 62(48): 273-279.

Gomez, K.A. and A.A. Gomez (1984). Statistical Procedures for Agricultural Research. John Willey and Sons. Inc. New York. U.S.A

Hamissa, A.M.; P.M. Hammouda and R.E. Knany (2000). Response of nodulated faba bean crop to phosphate soiubilizing bacteria under phosphorus fertilization and copper foliar spray application. J. Agric.Sci. Mansoura Univ., 25(5): 2995-3007.

Knany, R.E.; A.M. Masoud and Y.B. El-Waraky (2004).Comparative study between biofertilization and sulphur on availability of added phosphorus to faba bean plants under high $\mathrm{pH}$ soil conditions. J. Agric.Sci. Mansoura Univ., 29(8): 4801-4809.

Knany, R.E.; A.A. Abd El-Magid; H.G. Abu El-Fotoh and A.M. Hamissa(2000). Effect of addition of sulphur, phosphorus, potassium and some micronutrients, on soybean productivity and phosphorus utilization. Proc. IAOPN xth Internationa! Colloquium, Plant Nutrition for the next Millennium. Nutrients, quality and the Environment. April 813 Cairo. Egypt. Pub.. IAOPN-NRC pp. 169-175. 
Knany, R.E.; A.M. Masoud and A.M. Kaonsouh (2002). Impact of phosphorus fertilization and some micronutrients spraying on seed yield and quality of new cowpea cultivars. 2nd Inter. Conf. Hort. Sci. 10-12 Sept. Kafr El-Sheikh, Tanta Univ. Egypt. Pub. Tanta Univ. J. Agric. Res. 28:1035-1047.

Knany, R.E.; R.H. Atia and A.S.M. El-Saady (2005 a). Effect of different tillage practices, nitrogen sources and nitrogen levels on sugar beet yield and juice quality. Alexandria Sci. Exchange J. 26(3): 217-223.

Knany, R.E.; A.S.M. El-Saady; R.H. Atia and N. M.M. Awad (2005 b).Response of sugar beet to different seedling methods, phosphorus fertilizer management and spraying with some nutrients. J. Agric. Sci. Mansoura Univ., 30(12): 8249-8258.

Le-Docte, A. (1927). Commercial determination of sugar in the beet root using the sacks. Le-Docte process. Int.Sug. J. 29, 488-492.

Mahmoud, S.H. (2001). Response of garlic plants C.V. Chinese to rate and time of phosphorus application. The 5th Arabian Hort. Conf. Ismailia,Egypt. 69-74.

Mahmoud, S.A.Z and A.M. Abd El-Hafez (1982). The role of phosphate mobilizing bacteria in plant nutrition. The 1st OAU/STRC Inter. African Conf. on Biofertilizers, Cairo, Egypt.

Sayed, K.M.; R.E. Knany; A.I.N. Abdel Aal and A.S.A. Abdel-Mawgoud (1998). Subsoiling plow and nitrogen fertilizer types in relation to quality of sugar beet. J. Agric. Sci. Mansoura Univ., 23(12): 63236333.

Shafeek, M.R. (2003). Productivity of broad bean plants as affected by methods and times of phosphorus application. Annals Agric. Sci. Ain Shams Univ., Cairo, 48(2): 703-715.

Taieb, A.Z. (1990). The demands and constrains of energy utilization in sugar beet crop production. Ph.D. Thesis (Ag. Eng.) Cairo Univ.

Taieb, A.Z. (1997). Comparative study on manual and mechanical sugar beet planting in the newly reclaimed lands. Misr. J. Agric. Eng., 14(3): 299309

Verma, DP.; B.R. Sharma; AP.S. Chadha; H.K. Bajpai and U.P.S. Bhaduria (1996). Response of garlic (Allium sativum L.) to nitrogen, phosphorus and potassium levels. Plant Sci., 9(2): 37-41.

Voth, R.D. (1978). Effect of boron and manganese fertilizers on yield, quality and nutrition of sugar beet. C.f. Field Crops Abstracts. Vol., 34, No. 2. 
Sahar, F. Tawfic.

دراسة تأثير طرق الزراعة والسماد الفوسفاتي والرش ببعض المغذيات على إنتاجية

وجودة بنجر السكر في الأراضي الجديدة والئي



معهد بحوث المحاصيل السكرية_مركز البحوث الزراعية_الجيزة

أجريت تجربتان حقلينان في موسمي 2013/2012 - 2014/2013 في منطقة النوبارية بمحافظة



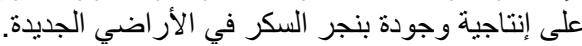

تحسين نواتج الجذور والسكر في بنجر السكر عملية صعبة، بسبب العلاقة العكسية بين تركيز السكر



لهذه الأسباب أقيمت هذه التجربة بمنطقة النوبارية - محافظة الإسكندرية- جمهورية مصر العزبية العربية

خلال موسمي 2012/2013 - 2014/20013.

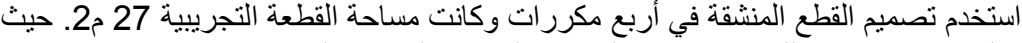

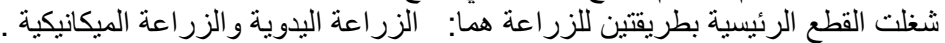

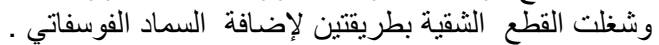



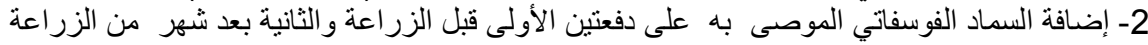

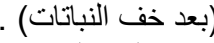
كما شغلت القطع تحت الثقية الثانية بأربع معاملات رش هي : 1- 1ا الرش بالماء (معاملة المقارنة) .

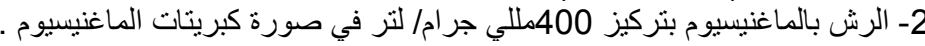



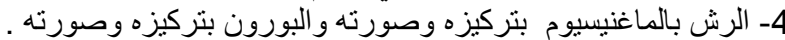
وقد أوضحت النتائج المتحصل عليها أنسان:



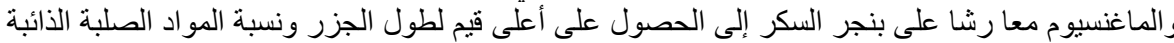

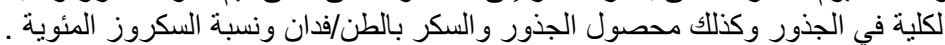

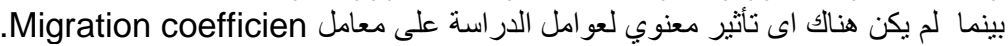

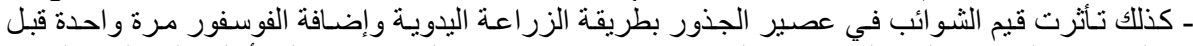

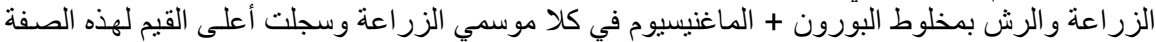

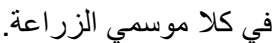

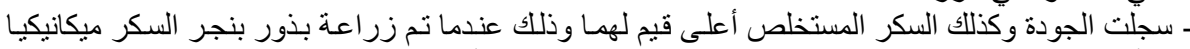

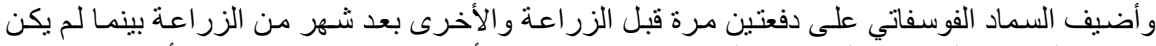


كلا موسمي الزر اعة على هاتين الصفنتين. 